For example, a child who had a deep laceration of the palm treated primarily by skin closure only and who was later referred to us had his hand immersed in water for half an hour at $40^{\circ} \mathrm{C}$. The skin on the thumb and index fingers and the ulnar border of the little finger shrivelled normally, while the skin on the fingers with loss of sensation-that is, middle, ring, and radial border of little fingers-remained quite smooth. There was also a typical damaged area on the tip of the anaesthetic middle finger. At exploration we found that the situation in the palm was exactly as expected.

Another patient had an ulnar nerve lesion after a motor cycle accident, resulting in pain and tenderness at the elbow. The hand and forearm were immersed in water, resulting in shrivelling of the skin on four digits, the little finger remaining smooth (fig. 1). At exploration about $3 \mathrm{~cm}$ above the medial epicondyle an ulnar nerve neuroma was found.

The result of an extensive injury in the palm requiring tendon graft and multiple nerve repairs in a third patient is shown in fig. 2. His index finger at this stage was quite numb, and it remained smooth after testing, while the skin on the other fingers shrivelled normally.

\section{Discussion}

An objective method of testing and assessing innervation in the hands is of much more value than traditional subjective tests, which depend not only on the patient's co-operation and concentration but also on his intelligence. Moberg's (1958) fingerprinting test is objective and accurate, but requires special equipment. The present test requires nothing more than a basin of warm water for 30 minutes. It is objective, accurate, and shows not only sensory loss, but also the progress of sensory recovery.

I wish to acknowledge the patient's mother's astute observation of this phenomenon in her son's hand and to thank her for drawing my attention to it. I am also indebted to $\mathrm{Mr}$. Scully and the photographic staffs in the hospitals concerned.

\section{References}

Moberg, E. (1958). Fournal of Bone and foint Surgery, 40B, 454. Seddon, H. J. (1954). Medical Research Council. Special Report Series, No. 282. London, H.M.S.O

Weber, E. H. (1835). Archiv fur Anatomie, Physiologie und Wissenschaftliche Medicin, p. 152 .

\title{
MEDICAL MEMORANDA
}

\section{Lassa Fever in Britain: An Imported Case}

\author{
A. W. WOODRUFF, T. P. MONATH, A. A. F. \\ MAHMOUD, A. K. PAIN, C. A. MORRIS
}

British Medical fournal, 1973, 3, 616-617

The diagnosis of Lassa fever has been made in a patient at the Hospital for Tropical Diseases, London, who arrived in Britain by air from West Africa and was at the time of admission suffering from pyrexia of unknown origin. The infection is among the most dangerous of those currently known; mortality rates of $36-52 \%$ have been reported for hospitalized cases in the few outbreaks so far known. This report is therefore made with the object of bringing to the notice of practitioners the main features of the disease, particularly in so far as they influence the recognition and management. The complement fixation tests on serum from this patient and on other sera that were examined at the time enabled it to be shown that an outbreak of fever present in Sierra Leone was caused by the Lassa virus.

Another patient who recently arrivived in Britain from West Africa has been admitted to the Hospital for Tropical Diseases, London, and it is probable that she has been infected

Medical Unit, Hospital for Tropical Diseases, London N.W.1.

A. W. WOODRUFF, M.D., F.R.C.P., Physician and Welcome Professor of Clinical Tropical Medicine

A. A. F. MAHMOUD, M.B., PH.D., Registrar

A. K. PAIN, M.B., B.s., Registrar

Public Health Service, U.S. Department of Health, Education and Welfare, Atlanta, Georgia, U.S.A.

T. P. MONATH, M.D., Chief of Arbovirology Section

Catholic Mission Hospital, Panguma, via Hangha, Sierra Leone C. A. MORRIS, M.B., D.T.M. \& H., Medical Officer

\section{Case Report}

A 35-year-old nursing sister at the Catholic Mission Hospital at Panguma, Sierra Leone, developed generalized aches and pains. Four days later she felt exhausted, developed a temperature of $101^{\circ} \mathrm{F}\left(38.3^{\circ} \mathrm{C}\right)$, and her temperature did not finally settle for another 20 days. The day after onset of the fever she became nauseated and had a headache. There were no other symptoms or physical findings. Malaria parasites were not seen in blood films, but a full course of chloroquine treatment was given without observable effect. One week before the onset of her symptoms the patient had pricked her finger with the needle of a syringe she had used for taking blood from a patient with pyrexia of unknown origin who had died the next day. There had been at least eight deaths among patients suffering from pyrexia of unknown origin in the Panguma area during the preceding six months.

On admission to hospital in London the patient's salient symptoms were severe pains in the limbs, described "as though the bones were breaking," together with headache and excruciating back pains confined to a narrow level around the fourth and fifth lumbar vertebrae. The day after admission she vomited on two occasions; she was anorectic and nausea persisted on and off throughout her illness. Prostration and weakness were severe. She was febrile and, apart from two days, remained so for two weeks with relative bradycardia (see chart). The blood pressure was $90 / 60 \mathrm{~mm} \mathrm{Hg}$ and thereafter fluctuated between this level and $115 / 75 \mathrm{~mm} \mathrm{Hg}$. There was no rash, sore throat, faucial injection, lymphadenopathy, oedema of face or neck, or abnormal bleeding.

Findings on admission were: haemoglobin $12.6 \mathrm{~g} / 100 \mathrm{ml}$; white cells $4,700 / \mathrm{mm}^{3}$ (normal differential); platelets plentiful; reticulocytes $0.4 \%$ E.S.R. (Westergren) $13 \mathrm{~mm}$ in the first hour; prothrombin ratio 1. Twelve days after admission these were haemoglobin 12.4 $\mathrm{g} / 100 \mathrm{ml}$; white cells $4,200 / \mathrm{mm}^{3}$ (normal differential); reticulocytes $1.4 \%$; E.S.R. $58 \mathrm{~mm}$ in the first hour. Twenty-five days after admission: haemoglobin $11.7 \mathrm{~g} / 100 \mathrm{ml}$; packed cell volume $35.3 \%$; white cells $6,500 / \mathrm{mm}^{3}$ (normal differential); reticulocytes $4.4 \%$; E.S.R. $23 \mathrm{~mm}$ in the first hour. A midstream specimen of urine contained $30 \mathrm{mg}$ albumin/ $100 \mathrm{ml}$ and a few pus and red cells in the centrifuged deposit. Cultures yielded no significant growth. Stool examination by micropsy and culture showed no protozoal, helminthic, or pathogenic bacterial infection. No malaria or other parasites were found on blood examination, and blood culture on two occasions produced no growth after three weeks' incubation. The Widal test gave titres of less than 20 to the $H$ and $O$ antigens of Salmonella typhi, S. paratyphi $A, S$. paratyphi $B$, and $S$ para- 

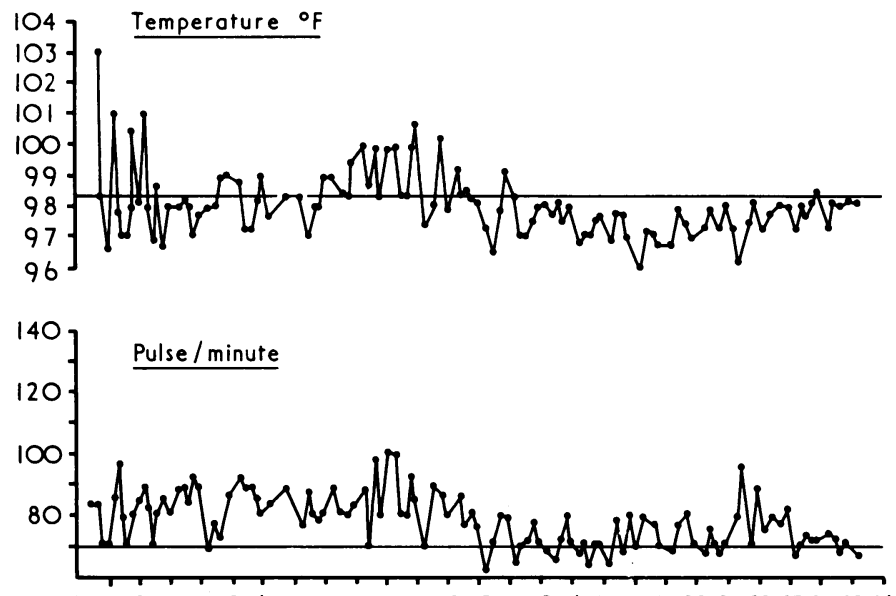

0 \begin{tabular}{llllllllllllllllllllll}
\hline & 2 & 4 & 5 & 6 & 7 & 8 & 9 & 10 & 11 & 12 & 13 & 14 & 15 & 16 & 17 & 18 & 1920 & 21 & 22 & 2324 & 2526
\end{tabular} Days of observation

Pulse rate and temperature variations.

typhi $C$. Brucella abortus and B. melitensis agghutinins were negative in all dilutions tested. Schistosomal and filarial complement fixation tests, filarial antibody test, and tests for Australian antigen and antibody were also negative. The toxoplasma dye test titre was 1/16. High vaginal swab cultures were sterile after four days' incubation. Gastric lavage yielded no acid-fast bacilli, and cultures for Mycobacterium tuberculosis were negative.

Except for a blood urea of $34 \mathrm{mg} / 100 \mathrm{ml}$ on the second day after admission the blood chemical values and liver function tests were within normal limits. Radiography of the chest, lumbar spine, and sacroiliac joints showed nothing abnormal except for mild sclerosis of the lateral surface of the sacroiliac joint margins.

\section{LASSA FEVER COMPLEMENT-FIXING ANTIBODIES}

The complement fixation (C.F.) test with Lassa virus as antigen was positive 8 and 14 weeks after the onset of the patient's illness at a titre of $1 / 8$. The tests done in microtitre plates by the method of Casey (1965). Serial twofold dilutions of each serum (starting at 1/2) were tested against twofold dilutions of Lassa antigen in a "box titration," and the serum titre was expressed as the highest dilution of serum fixing five units of complement. The antigen was produced from Vero cell cultures grown in 32-oz (907 $\mathrm{ml}$ ) bottles and infected with $10^{5}$ Vero plaque-forming units of Lassa virus, Pinneo strain, which had previously undergone two passages, one in mice and one in Vero cells. Cultures were maintained with commercially prepared medium (Plus 1 medium, Lab Cell Suppliers, Frederick, Md.) and were harvested after six days, when cells showed about $3+$ degeneration. Preliminary studies had indicated that Lassa antigen remained largely cell associated, and therefore both the extracellular fluid and the cells were harvested. The mixture was rapidly frozen and thawed several times and used as antigen in C.F. tests without centrifugation. Control antigen was prepared from similarly treated uninfected cultures. In titrations against reference antisera the cell culture antigen was shown to be as potent as previously available antigens prepared from infected mouse brains and to be relatively free from nonspecific anticomplementary reactions when tested against large numbers of human sera.

Not enough is known about the intensity and duration of C.F. antibody responses to infection with Lassa virus. The available data suggest that C.F. titres are generally low-1/16 to 1/64-during the months after infection. Though our patient's C.F. response was low her serum reacted with absolute specificity, even at the $1 / 2$ dilution.

\section{Comment}

Lassa fever was first reported from Lassa, N.E. Nigeria, in 1969 (Frame et al., 1970). A further outbreak around Jos, Nigeria, was described by Troup et al. (1970). Studies of this outbreak were reported by Edington and White (1972), Carey et al. (1972), and Henderson et al. (1972). Probably the disease is more widespread than was formerly suspected and many less severe cases occur.

The virus is related to the viruses of lymphocytic choriomeningitis and the Tacaribe complex (Buckley and Casals, 1970) and with them has been considered to be a member of a new group for which the name arenoviruses has been proposed (Rowe et al., 1970). The mode of transmission to man is unknown, but a rodent reservoir for the causative virus is suspected. Outbreaks among those coming into contact with known patients are common and many deaths have resulted. Hospital staff are particularly at risk because transmission probably occurs from virus excreted in urine, stools, vomit, and respiratory droplets. Transmission in infected blood is also virtually certain. Patients must be strictly isolated and particular care taken in handling and disposing of their clothing, bed linen, excretions, and laboratory specimens.

Features that suggest the diagnosis include not only severe headache and backache associated with fever, particularly fever maintained at a minimum of $100^{\circ} \mathrm{F}\left(37.8^{\circ} \mathrm{C}\right)$ for a week or more, but also abdominal or chest pain, a bleeding tendency, pharyngitis, leucopenia, hypotension, alopecia, and deafness. A critical period is the second week of the illness, when even those who seem to be doing well may suddenly collapse. The appearance on the faucial pillars of discrete spots of whitish epithelium or exudate $2-10 \mathrm{~mm}$ in diameter which cannot be wiped away is strongly suggestive of Lassa fever.

Convalescent plasma or serum has so far been given in only six cases, and in five of these it was followed by significant improvement in the patient's condition. About $250 \mathrm{ml}$ of serum from a fully convalescent patient is given in order not to risk infecting a recipient wrongly suspected of having the disease. A difficulty is that a positive diagnosis may have to wait until the finding of Lassa antibodies about four weeks after the onset of fever, whereas a critical period in the illness may arise at 7 to 10 days. Fine clinical judgement is clearly required.

Lassa fever should be considered in all patients presenting with suggestive clinical and epidemiological features (British Medical fournal, 1972). Doctors who see a suspicious case are recommended to contact either the Hospital for Tropical Diseases, London (Tel. 01-387-4411), or the Liverpool School of Tropical Medicine (051-709-7611).

\section{References}

British Medical fournal, 1972, 4, 253.

Buckley, S., and Casals, J. (1970). American fournal of Tropical Medicine and Hygiene, 19, 680 .

Carey, D. E., et al. (1972). Transactions of the Royal Society of Tropical Medicine and Hygiene, 66, 402.

Casey, H. L. (1965). Public Health Monograph, No. 74, U.S. Department of Health, Education and Welfare.

Edington, G. M., and White, H. A. (1972). Transactions of the Royal Society of Tropical Medicine and Hygiene, 66, 381.

Frame, J. D., Baldwin, J. M., Gocke, D. J., and Troup, J. M. (1970). American fournal of Tropical Medicine and Hygiene, 19,670.

Henderson, B. E., Gary, G. W., jun., Frame, J. D., Carey, D. E., and Kissling, R. E. (1972). Transactions of the Royal Society of Tropical Medicine sling, R. E. (1972). Trans

Rowe, W. P., et. al. (1970). Fournal of Virology, 5, 651

Rowe, W. P., et. al. (1970). fournal of Virology, 5, 651.
Troup, J. M., White, H. A., Fom, A. L. M. D., and Carey, D. E. (1970). American fournal of Tropical Medicine and Hygiene, 19, 695. 